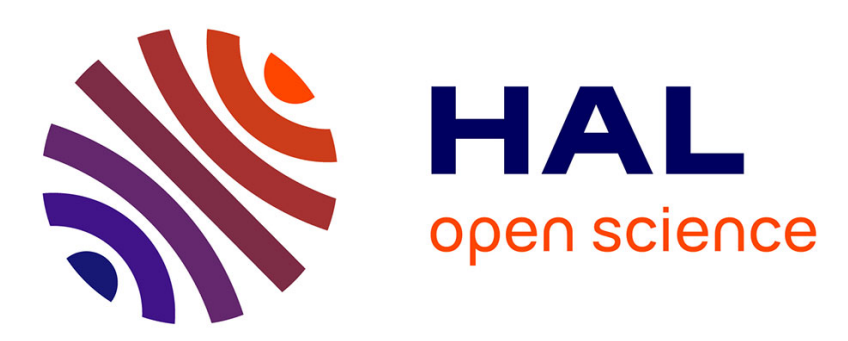

\title{
Preconcentration and Successful Selective Detection of Traces of Diclofenac in Water using a Nanostructured Modified Carbon Paste Electrode
}

Siham Amra, Mustapha Bourouina, Saliha Bourouina Bacha, Didier Hauchard

\section{- To cite this version:}

Siham Amra, Mustapha Bourouina, Saliha Bourouina Bacha, Didier Hauchard. Preconcentration and Successful Selective Detection of Traces of Diclofenac in Water using a Nanostructured Modified Carbon Paste Electrode. Electroanalysis, 2021, 33 (4), pp.936-946. 10.1002/elan.202060415 . hal03122486

\section{HAL Id: hal-03122486 \\ https://hal.science/hal-03122486}

Submitted on 5 Feb 2021

HAL is a multi-disciplinary open access archive for the deposit and dissemination of scientific research documents, whether they are published or not. The documents may come from teaching and research institutions in France or abroad, or from public or private research centers.
L'archive ouverte pluridisciplinaire HAL, est destinée au dépôt et à la diffusion de documents scientifiques de niveau recherche, publiés ou non, émanant des établissements d'enseignement et de recherche français ou étrangers, des laboratoires publics ou privés. 


\title{
Preconcentration and successful selective detection of traces of diclofenac in water using a nanostructured modified carbon paste electrode
}

\author{
Siham AMRA ${ }^{\mathrm{a}, \mathrm{b}}$, Mustapha BOUROUINA ${ }^{\mathrm{a}}$, Saliha BOUROUINA BACHA ${ }^{\mathrm{c}}$, Didier HAUCHARD \\ ${ }^{a}$ Département de Chimie, Faculté des Sciences Exactes, Université A. Mira, Bejaia 06000, Algérie

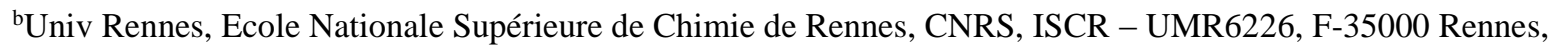 \\ France \\ 'Département de Génie des procédés, Faculté de technologie, Université A. Mira, Bejaia 06000, Algérie
}

Corresponding author: AMRA Siham ／Ｐhone No: +33629618654 / Email: stytyme@ @ hotmail

\section{Acknowledgements}

My thanks go to the Algerian Ministry of Higher Education and Scientific Research for their financial support; ERDF, Brittany Region and Rennes Métropole for their contribution and the CMEBA center of ISCR-CNRS6226 for the SEM analyses. 


\begin{abstract}
A highly sensitive, simple and low cost sensor for the quantification of the diclofenac has been constructed. This sensor consists of a carbon paste nano-structured by Multi-Walled Carbon Nanotubes (G-MWCNT)-CPE. Scanning electron microscopy (SEM) and voltammetry technique were used to characterize the electrode material and to determine the analytical performances of the sensor in comparison with those obtained at a G-CPE. The electrochemical oxidation of diclofenac on both G-CPE and (G- MWCNT)-CPE electrodes is mainly controlled by adsorption, presenting a maximum peak current intensity in $\mathrm{H}_{2} \mathrm{SO}_{4} 0.5 \mathrm{~mol} \mathrm{~L}{ }^{-1}$. The carbon nanotubes, as well as they provide higher conductivity of the paste, act as spacers between the flake graphite particles and avoid their stacking in order to make the surface of graphite particles more accessible to DCF adsorption. The voltammetric measurements of diclofenac on (G-

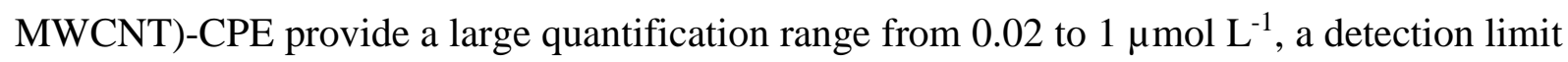
of $0.004 \mu \mathrm{mol} \mathrm{L} \mathrm{L}^{-1}$ and quantification limit of $0.014 \mu \mathrm{mol} \mathrm{L}^{-1}$ under the optimized operating conditions $\left(\mathrm{H}_{2} \mathrm{SO}_{4}, 0.25 \mathrm{M}+\mathrm{KCl} 0.25 \mathrm{M}\right.$, scan rate of $30 \mathrm{mV} \mathrm{s}^{-1}$, preconcentration time 18 min. and MWNTC\% (30\%)). The (G- MWCNT)-CPE sensor was successfully applied to natural water samples, just acidified with sulfuric acid $(\mathrm{pH}<1)$. These samples were doped with diclofenac in sub-micromolar range and the developed method was validated with excellent recoveries (within a maximum of $3 \%$ difference from 100\%) for all samples indicating no interference effects of the water matrix.
\end{abstract}

\title{
Graphical abstract :
}

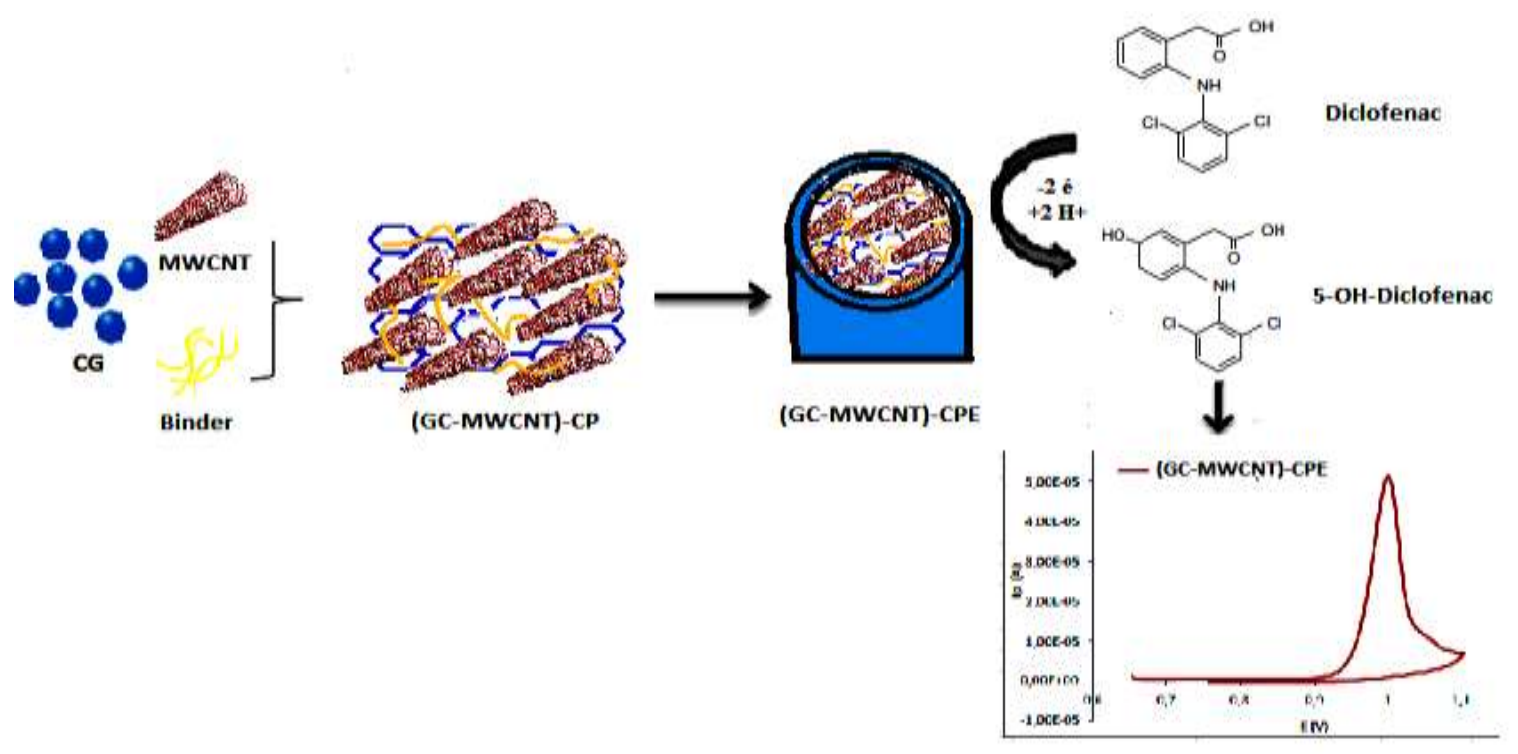


Keywords: Carbon Paste Electrode; Multi-walled carbon nanotubes; diclofenac; trace analysis; voltammetry.

\section{Introduction}

Diclofenac (DCF), 2-(2,6-dichloranilino) phenylacetic acid (Scheme 1), anti-inflammatory drug with strong antipyretic and analgesic effect [1], is one of the most commonly used pain killers, in the form of sodium salt [2]. This medicine is widely used in a variety of medical treatment. It's prescribed as an analgesic for postoperative conditions, musculoskeletal injuries, chronic inflammations, degenerative diseases and rheumatic conditions $[3,4]$.

Due to its intensive use, diclofenac causes diffuse pollution, difficult to treat, it is weakly eliminated in treatment plants. It is present in waters at very low concentrations between 1 and $10 \mu \mathrm{g} \mathrm{L}^{-1}$ [5]. These residues can be regularly detected in the surface waters of the world [6]. Diclofenac is one of the pharmaceutical products added to the watch list defined by the WFD of the European Union [7]. Studies show that prolonged exposure leads to deterioration in the overall health of fish, causing damage to the kidneys and gills even at very low concentrations of $5 \mu \mathrm{g} \mathrm{L}^{-1}$ [8].

Therefore, its monitoring in the environment and the control of water quality is of major importance. Indeed, several techniques are already used for the quantification of diclofenac, in between others, HPLC [9, 10], HPLC-MS [11, 12], GC [13], GC-MS [14], spectrophotometry [15], capillary electrophoresis [16], etc. In addition, electrochemical techniques are very interesting for their high sensitivity, selectivity, low cost, short response time and easy implementation. These advantages have particularly encouraged the development of sensors for the assessment of diclofenac in various liquid samples.

Among others, carbon paste electrodes (CPEs) are widely used for the analysis of residues of various pollutants because of the possibility of modifying them with nanostructure materials such as multiwall carbon nanotubes (CNTs) $[18,19]$. Indeed, the particular chemical, electrical, mechanical and structural properties of CNTs have led to the development of a variety of detection applications. CNTs promote charge transfer reactions and therefore improve the analytical characteristics of the sensor [20-22].

In the current study, modified CPEs incorporating multi-walled carbon nanotubes ((GMWCNT)-CPE) were applied for the trace detection and quantification of diclofenac in aqueous solution, using voltammetry technique. It appears that the method developed is simple, 
selective, fast and very sensitive for the determination of traces of diclofenac in real water samples with good repeatability and reproducibility.

Scheme 1: Chemical structure of diclofenac

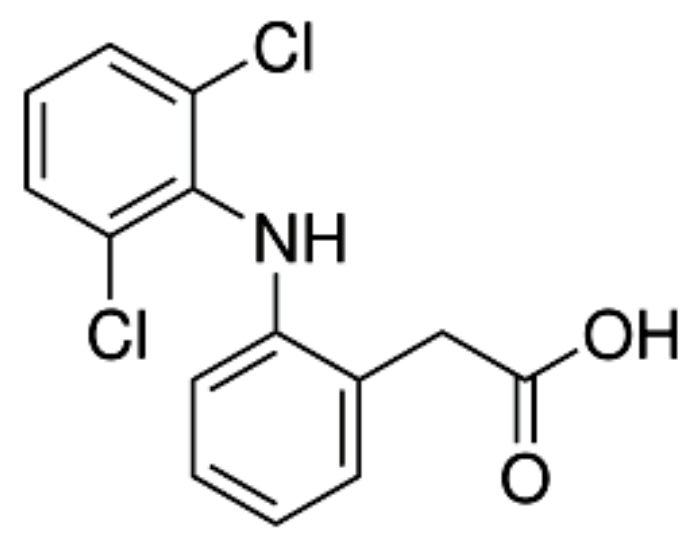

\section{Experimental}

\subsection{Reagents and Materials}

All reagents used were of analytical quality (highest available purity) and were used as received. Graphite powder $(\mathrm{G})(<20 \mu \mathrm{m})$, multiwalled carbon nanotubes $(D \times L: 110-170 \mathrm{~nm} \times 5-9 \mu \mathrm{m})$, Nujol (mineral oil), sulfuric acid (for analysis EMSURE, 98\%), ethanol (99\%), diclofenac (analytical standard 99.9\%) were purchased from Sigma-Aldrich, potassium chloride (EMSURE for analysis, Supelco). The $\mathrm{pH}$ value of aqueous solutions was adjusted using $\mathrm{NaOH}$ (Sigma-Aldrich, 98\%) and controlled with a Metrohm pH meter (pH Lab 827 and combined glass electrode). All aqueous solutions were prepared with ultrapure water at $18.2 \mathrm{M} \mathrm{cm}\left(20^{\circ}\right.$ C). Stock solutions of diclofenac $(0.1 \mathrm{M})$ were prepared with ethanol and the daughter solutions were prepared with ultrapure water and then stored at $4{ }^{\circ} \mathrm{C}$ in the dark.

All experiments performed in this work were carried out at room temperature $\left(20 \pm 1^{\circ} \mathrm{C}\right)$.

\subsection{Instrumentation}

All electrochemical experiments were carried out using a PGSTAT 220 Metrohm potentiostat/galvanostat in combination with NOVA 2.0 software. The electrochemical measurements were carried out using a conventional three-electrode electrochemical cell, consisting of a platinum wire as auxiliary electrode and an $\mathrm{Ag} / \mathrm{AgCl}(3 \mathrm{M} \mathrm{KCl})$ as reference 
electrode. The working electrode consists of a conventional carbon paste electrode (CPE) without or with the incorporation of multi-walled carbon nanotubes in various proportions.

The material morphology of Carbon graphite $(\mathrm{G})$, multi-walled carbon nanotubes (MWCNT) and their mixture (G- MWCNT)- $\mathrm{CP}_{3}$ was characterized using a scanning electron microscope (JEOL JSM-7100F, EDS detector Oxford Instrument $50 \mathrm{~mm}^{2}$ ).

\subsection{CP electrodes preparation}

The carbon paste electrodes (CPE) were made by hand mixing its components in the desired proportions with the desired amount of binder (Nujol) until a well homogeneous paste was obtained (about 30 minutes). The resulting paste was then transferred into the cavity at the end of a home-made teflon cylindrical tube ( $2 \mathrm{~mm}$ deep and $3 \mathrm{~mm}$ internal diameter) hermetically surrounding a graphite bar acting as an electrical contact. Subsequently, the surface was smoothed by rubbing the electrode several times slowly on paper.

Four carbon pastes (CPs) of different composition (\% by weight) were prepared: (i) graphite powder $(80 \%)$ and binder $(20 \%)$ (G-CP), (ii) graphite powder $(70 \%)$, binder $(20 \%)$ and multiwalled carbon nanotubes $(10 \%)\left((\mathrm{G}-\mathrm{MWCNT})-\mathrm{CP}_{1}\right)$, (iii) graphite powder $(60 \%)$, binder (20\%) and Multiwalled carbon nanotubes (20\%) ((G-MWCNT) $\left.-\mathrm{CP}_{2}\right)$ and (iv) graphite powder $(50 \%)$, binder (20\%) and multiwalled carbon nanotubes (30\%) (G-MWCNT) $\left.-\mathrm{CP}_{3}\right)$.

\subsection{Real samples preparation}

The (G-MWCNT) $-\mathrm{CPE}_{3}$ was applied for the determination of diclofenac in local tap water and lake water (Dezedeul pond in Cesson-Sevigne, Brittany France). The two samples were filtered with a syringe filter $(0.45 \mu \mathrm{m}, \Phi=0.33 \mathrm{~mm})$ and enriched with hundreds of nanomolar diclofenac concentration and then stored in the dark at $4^{\circ} \mathrm{C}$. Before measurements by voltammetry, concentrated $\mathrm{H}_{2} \mathrm{SO}_{4}$ and $\mathrm{KCl}$ salt were added to have for each electrolyte a concentration of $0.25 \mathrm{M}$ (measured $\mathrm{pH}=0.5$ ). The diclofenac concentration measurements were determinate by a standard addition method under optimal conditions.

\section{Results and discussion}

\subsection{SEM characterization of G, MWCNT and (G- MWCNT)-CP3}


The morphologies of modified electrodes have been explored using scanning electron microscope (SEM). Fig. 1 displays SEM images of G (A), MWNTC (B) and their mixture in the (G-MWCNT) -CP (C). One can see on the image (A) the typical flake morphology of the graphite particles and on the image (B) entangled nanotubes (MWCNT). While on the SEM image (C) appears a mixture composed of G particles and MWCNT ensuring electrical contact between all components of the so prepared carbon paste. Moreover, it can be clearly seen that the mixture $(\mathrm{C})$ provides us with a very rough and spongy surface; this provided us with a large contact surface and a more important interaction with the analysed compounds.

\section{Insert Figure 1}

\subsection{Voltammetric studies}

\subsubsection{Effect of the paste composition on CPE response of diclofenac}

The electrochemical behavior of diclofenac was investigated at the CP- electrode by using voltammetry technique in the potential range of $0-1.1 \mathrm{~V}$ vs. $\mathrm{Ag} / \mathrm{AgCl}$ at a scanning rate of 30 $\mathrm{mV} \mathrm{s}^{-1}$.

The voltammograms were recorded for $5.0 \times 10^{-6} \mathrm{~mol} \mathrm{~L}^{-1}$ diclofenac solution at a (G)-CPE (Fig.2-a) and (G-MWCNT)-CPE 3 (Fig.2-b). As one can observe the current of the oxidation peak (Ip) increases significantly thanks to the presence of multi-walled carbon nanotubes MWCNT (30\%) in the paste. This enhancement in sensitivity is probably due to the increase in the active surface of the electrode assuring a better electron transfer and consequently an improvement of the electrochemical properties [22]. The peak shape of the $\mathrm{CV}$, in the presence of MWCNT in the carbon paste, is a characteristic of the oxidation of the diclofenac adsorbed on the electrode material.

To optimize the amount of MWCNT in the sensor, various mass compositions including 50$80 \%$ graphite, $20 \%$ of paraffin and an amount of $10-30 \%$ by mass of MWCNTs were examined. The voltammograms of the Diclofenac solution at modified CP electrodes with different MWCNT masses were obtained in an aqueous solution containing $\mathrm{H}_{2} \mathrm{SO}_{4} 0.25 \mathrm{M}+\mathrm{KCl} 0,25$ $\mathrm{M}$ and recorded in the potential range $0-1.1 \mathrm{~V}$ vs $\mathrm{Ag} / \mathrm{AgCl}$ at a scan rate of $30 \mathrm{mV} \mathrm{s}^{-1}$ for four levels of Diclofenac concentration (5 10-8; $510^{-7} ; 310^{-6} ; 510^{-6} \mathrm{~mol} \mathrm{~L}^{-1}$;Fig. 3).

A linear relationship between Ip and DCF concentration was observed $\left(\mathrm{R}^{2}>0.998\right)$ in this large concentration range of four decades for the different proportions MWCNTs in the paste. The 
best sensitivity is recorded for the (G-MWCNT) $-\mathrm{CPE}_{3}$, which indicates that the addition of the MWCNTs (30\%) has considerably improved the electrochemical signal thanks to their very interesting characteristics such as good electrical conductivity, high surface area and high chemical stability [23]. Moreover, the carbon nanotubes, as well as they provide higher conductivity of the paste can play a role of spacers between the flake graphite particles and avoid their stacking in order to make the surface of graphite particles more accessible.

\section{Insert Figure 3}

\subsubsection{Influence of pre-concentration time}

Detection of traces of diclofenac depends on its adsorption on the CPE, so the waiting time before the voltammetry analysis can significantly affect the current intensity of diclofenac oxidation. Indeed, the influence of the waiting time on the sensor response was examined in an aqueous solution containing a concentration of $210^{-7} \mathrm{~mol} \mathrm{~L}^{-1}$ of diclofenac under magnetic stirring (300 rpm). As can be seen in Fig. 4, the oxidation peak current increases with time and reaches a maximum at 18 minutes. Beyond and up to 22 minutes no change was observed indicating that the absorption equilibrium of diclofenac on the electrode (GMWCNT)-CPE 3 is reached in less than 20 minutes with $\mathrm{H}_{2} \mathrm{SO}_{4} 0.25 \mathrm{M}+\mathrm{KCl} 0,25 \mathrm{M}$ electrolyte.

\section{Insert Figure 4}

\subsubsection{Effect of potential scan rate}

The dependence of the response of the oxidation current of diclofenac on the potential sweep rate was examined at the electrode (G-MWCNT)-CPE 3 by a voltammetry technique for $10^{-6} \mathrm{~mol} \mathrm{~L}^{-1}$ of diclofenac, in $\mathrm{H}_{2} \mathrm{SO}_{4} 0.25 \mathrm{M}+\mathrm{KCl} 0,25 \mathrm{M}$, for five potential scan rates in the range 10-50 $\mathrm{mV} \mathrm{s}^{-1}$ (Fig. 5) (higher scan rates leading to voltammograms distortion). DCF oxidation current peaks increased with increasing scan rate $v$. The linear relationship $(\mathrm{R}=0.999)$ between Ip and $v$ (curve-Fig. 5) indicates that the electrode process is a surface controlled process.

\section{Insert Figure 5}

\subsubsection{Effect of pH}


A study to determine the best supporting electrolyte for the proposed method was carried out with 4 electrolytes: $\mathrm{H}_{2} \mathrm{SO}_{4} 0.5 \mathrm{~mol} \mathrm{~L}{ }^{-1}, \mathrm{HCl} 0.5$ mol.L ${ }^{-1}$, phosphate buffer 0.1 mol.L $\mathrm{L}^{-1}(\mathrm{pH}=1)$ and $\mathrm{H}_{2} \mathrm{SO}_{4} 0.25 \mathrm{M}+\mathrm{KCl} 0,25 \mathrm{M}$. The best resulting responses for diclofenac were obtained with $\mathrm{H}_{2} \mathrm{SO}_{4}$ as acidic electrolyte and addition of $\mathrm{KCl}$ allow to minimize the residual (capacitive) current. Therefore this supporting electrolyte $\left(\mathrm{H}_{2} \mathrm{SO}_{4} 0.25 \mathrm{M}+\mathrm{KCl} 0,25 \mathrm{M}\right)$ was chosen for further analysis. Indeed, the presence of $\mathrm{KCl}$ salt improved the response of the sensor as indicated elsewhere [17]. The effect of $\mathrm{pH}$ on the diclofenac oxidation at (G-MWCNT)-CPE 3 electrode was carried out by voltammetric method in the $\mathrm{pH}$ range of $0.5-4.0$ and for different concentrations of diclofenac $\left(0.4,0.7\right.$ and $\left.110^{-6} \mathrm{~mol} \mathrm{~L}^{-1}\right)$ in aqueous solution, containing $\mathrm{H}_{2} \mathrm{SO}_{4}$ $0.25 \mathrm{M}+\mathrm{KCl}$ 0,25 M. Three concentrations have been used in order to compare the sensitivity of the linear variation of Ip. As shown in Fig. 6, the lower the $\mathrm{pH}$ the sensitivity of the sensor (G-MWCNT) - $\mathrm{CPE}_{3}$ increases. Therefore, the best sensitivity was recorded at $\mathrm{pH}<1\left(\mathrm{H}_{2} \mathrm{SO}_{4}\right.$ $0.25 \mathrm{M}+\mathrm{KCl} 0,25 \mathrm{M}$ ), indicating that the acidity of the electrolyte has a positive impact on the adsorption of diclofenac on carbon paste and in accordance with involving of protons in the electro-oxidation reaction of diclofenac [24]. Thus, the $0.25 \mathrm{M}$ sulfuric acid solution at $\mathrm{pH}<1$ was considered the optimal support electrolyte and then used for all experiments. In addition, the anodic peak potential (Epa) for the diclofenac oxidation at (C-MWCNT) $-\mathrm{CPE}_{3}$ showed a linear relationship with the $\mathrm{pH}$ (Fig.7). Which could be expressed as follows:

$$
\text { Epa }=-0,051 \mathrm{pH}+0,939 \quad\left(\mathrm{R}^{2}=0,990\right)
$$

The slope value is close to the theoretical value $0.059 \mathrm{~V} / \mathrm{pH}$ (Nernstian behavior at $293 \mathrm{~K}$ ) [25] in accordance with an equal number of electrons (n) and protons (m) involved in the electrochemical oxidation of diclofenac( slope of 2,3 RT (m / n) / pH for the Nernstian equation of Ep (V). This confirms the reaction mechanism proposed by different authors for the electro-oxidation of DCF at the electrode (G-MWCNT) -CPE (Fig.8) [29, 30]. With the intervention of two electrons and two protons $[27,28]$.

\section{Insert Figure 6, 7 and 8}

\section{Analytical validation of the proposed method}

\subsection{Calibration plots and detection limit (LOD)}

Calibration curve was constructed under optimal conditions: 0-1.2 V; sweep rate $30 \mathrm{mV} . \mathrm{s}^{-1}$ and preconcentration time of 18 min under stirring of the supporting electrolyte $\left(\mathrm{H}_{2} \mathrm{SO}_{4} 0.25 \mathrm{M}+\right.$ $\mathrm{KCl}$ 0,25 M). Fig. 9 shows the voltammograms obtained for different concentrations of 
diclofenac at (G-MWCNT) - CPE $_{3}$ electrode. As can be seen in fig. 9 the peak oxidation current

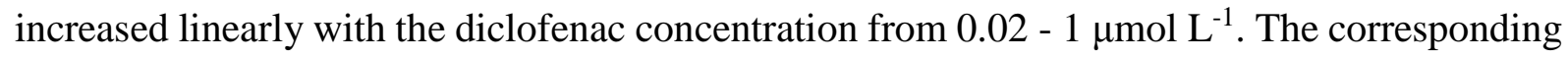
linear regression equation was expressed as $I \mathrm{p}(\mu \mathrm{A})=10.25 C+0.053\left(\mu \mathrm{mol} \mathrm{L}^{-1}\right)\left(\mathrm{R}^{2}=0.999\right)$. The detection limit (LOD) and quantification limit (LOQ) were calculated using the equation, $\mathrm{LOD}=3 S / \mathrm{m}$ and LOQ $=10 \mathrm{~S} / \mathrm{m}$, respectively [29]. Where $S$ is the standard deviation of peak current and $m$ is the slope of the calibration curve. The LOD and LOQ values were found to be $0.004 \mu \mathrm{mol} \mathrm{L}^{-1}$ and $0.014 \mu \mathrm{mol} \mathrm{L}{ }^{-1}$, respectively. With a LOD of 4 nanomolar (G-MWCNT)$\mathrm{CPE}_{3}$, associated with an electrolyte favorable to the adsorption of DCF, appears as a suitable sensor for DCF trace analysis.

\section{Insert Figure 9}

\subsection{Repeatability and reproducibility of the proposed method}

An evaluation of the repeatability of the proposed sensor (G-MWCNT) - $\mathrm{CPE}_{3}$ was performed using four concentrations of diclofenac with a maximum of $1 \mu \mathrm{mol} . \mathrm{L}^{-1}\left(1,4,7\right.$ and $1010^{-7} \mathrm{~mol}$ $\mathrm{L}^{-1}$ ). Four measurements with the same standard diclofenac solutions were obtained by voltammetry method under optimal operating conditions by using the same electrode and the mean values of $I \mathrm{p}$ are summarized in Table 1.

A good repeatability for four concentrations, expressed as a relative standard deviation (RSD) was obtained and with RSD didn't exceed 3.5\%.

The reproducibility of the current response for the four diclofenac concentrations was studied using four sensors, prepared independently by the same procedure under the same previously optimized operating conditions. The highest value of RSD (8.4\%) was obtained for $0.1 \mu$ mol.L${ }^{1}$ (table 1) indicating an acceptable reproducibility (RSD < 10\%) of the developed analytical method with the (G-MWCNT) - $\mathrm{CPE}_{3}$ sensor.

\section{Insert Table 1}

\subsection{Interferences effect}

Some compounds may be potential interferers and thus interfere with the analytical response of the developed sensor. (G-MWCNT) $-\mathrm{CPE}_{3}$ if they are in the sample to be analyzed. Thus, for the study of interference, various compounds were selected and tested: glucose, fructose, urea, sulfamethazine, ascorbic acid, vanilin, oxalic acid, caffeine; inorganic ions $\left(\mathrm{K}^{+}, \mathrm{Na}^{+}, \mathrm{PO}_{4}{ }^{2-}, \mathrm{Cl}^{-}\right.$ and $\mathrm{SO}_{4}{ }^{2-}$ ); other organic pollutants among which glyphosate, chlordecone, epoxiconazol, propazine, tebuconazol, atrazine and bisphenol A. 
In order to evaluate potential interferences, voltammetric measurements were made under optimal operating conditions, with solutions containing a concentration of $10^{-6} \mathrm{~mol} \mathrm{~L}^{-1}$ of diclofenac and $1 \mathrm{~mol} \mathrm{~L}^{-1}$ of $\mathrm{K}^{+}, \mathrm{Na}^{+}, \mathrm{PO}^{2-}, \mathrm{Cl}^{-}, \mathrm{SO}^{2-}$ and also in the presence of different organic compounds as potential interferences.

The presence of $\mathrm{K}^{+}, \mathrm{Na}^{+}, \mathrm{PO}_{4}{ }^{2-}, \mathrm{Cl}^{-}$and $\mathrm{SO}_{4}{ }^{2-}$ has no influence on the sensor current response. While, when $10^{-4} \mathrm{~mol} \mathrm{~L}^{-1}$ of glucose, sulfamethazine, urea, ascorbic acid, valine, oxalic acid or caffeine was added to the solution, we observed a slight change less than $5 \%$ in the current intensity as could be seen on Fig.10. However, the addition of $10^{-3} \mathrm{~mol} \mathrm{~L}^{-1}$ glucose, ascorbic acid and caffeine decrease the current intensity over than $5 \%$ and less than $18 \%$. Thus, for these compounds the tolerated limit should not exceed $10^{-4} \mathrm{~mol} \mathrm{~L}^{-1}$ which is never achievable concentration levels in water. In addition, when analyzing $10^{-5} \mathrm{~mol} \mathrm{~L}^{-1}$ of glyphosate, chlorodecone, epoxiconazole, propazine, tebuconazole, atrazine and bisphenol A, no signal was detected with (G-MWCNT)-EPC 3 in same operating conditions applied for the analysis of diclofenac. These results revealed that the proposed electrode, in this acidic electrolyte, present a high sufficient selectivity in the presence of excessive concentrations of organic and inorganic chemicals interferences. Even if we have not tested all the molecules that could oxidized in the potential range of DCF oxidation, we have not observed significant influence on the DCF peak current with the tested potentially interferents like ascorbic acid, caffeine, sulfamethazine. These molecule normally oxidize in the potential range $0.4-1.1 \mathrm{~V}$ but are rather hydrophilic molecules $(\log$ Kow $\leq 1.5)$ in comparison with dichlofenac which has a hydrophobic character $(\operatorname{logKow}=4.51)$. This is probably not the own reason that could explain this selectivity (logKow $>2$ for propazine, tebuconazole, atrazine with respectively 2.93, 3.7, 2.61). Indeed, the possibility of charge on molecule, in relation with $\mathrm{pKa}$ vatue for amine function, could be unfavorable to adsorption. Thus, the tested potential interferents (propazine, tebuconazole, atrazine) have $\mathrm{pKa}_{1}$ higher than 1 (respectively $\left.1.7 ; 2.3 ; 1.6\right)$ which indicates that they are positively charged in the protonated form for the case of our electrolyte $(\mathrm{pH}<1)$. These arguments are in accordance with the good selectivity of the modified CPE observed towards the detection of diclofenac in $\mathrm{H}_{2} \mathrm{SO}_{4} 0.25 \mathrm{M}+\mathrm{KCl} 0.25 \mathrm{M}$ electrolyte.

\section{Insert Figure 10}

\subsection{Analysis of real samples}

To evaluate the validity of the proposed method, the (G-MWCNT) $-\mathrm{CPE}_{3}$ was applied for the determination of diclofenac in samples of local tap water and lake water (Pond of Dezedeul in Cesson-Sevigne, Britanny France), after the addition of concentrated $\mathrm{H}_{2} \mathrm{SO}_{4}$ and solid $\mathrm{KCl}$ in 
order to obtain a concentration of $0.25 \mathrm{~mol} . \mathrm{L}^{-1}$ each. No traces of diclofenac were detected with the modified electrode in voltammetry (lower than LOD $0.004 \mu \mathrm{mol} \mathrm{L}{ }^{-1}$ ). Therefore, water samples were doped with hundreds nanomolar of diclofenac concentration level to validate voltammetric analysis in real samples. The measurements of diclofenac concentration in the doped samples were obtained by standard addition method under optimal conditions. The results were summarized in Table 1, the quantitative recoveries (\% recovery) and RSD (\% for 4 replicates) for tap water and lake water samples were respectively $101.9 \%, 2.5 \%$ and 98.9 $\%, 0.6 \%$,indicating no interference effects of the water matrix on the precision of DCF concentration values. Therefore, the proposed modified electrode could be applied directly in environmental samples for analysis of DCF with satisfactory results, just after acidification with $\mathrm{H}_{2} \mathrm{SO}_{4}$.

\section{Insert Table 2}

\section{Comparison with other reported methods}

The performances of the developed sensor have been compared to those of the other sensors used for the DCF quantification by different modified electrodes in the literature. The obtained analytical performances were resumed in Table 3. The Comparison of the data showed the superiority of the developed method compared to some previously reported methods, especially with regard to the range of linearity and the detection limit, revealing that the proposed sensor may be a good alternative method for the quantification of diclofenac trace analysis.

\section{Insert Table 3}

\section{Conclusion}

In the present study, a simple and sensitive electrochemical method for the determination of diclofenac was developed using a carbon paste electrode nanostructured with $30 \%$ multiwalled carbon nanotubes (G-MWCNT) $-\mathrm{CPE}_{3}$. Voltammetry technique was used to study the influence of $\mathrm{pH}$ on the anodic peak current of diclofenac and the electrolytic solution $\left(\mathrm{H}_{2} \mathrm{SO}_{4}\right.$ $0.25 \mathrm{M}+\mathrm{KCl}$ 0,25 M) was chosen as suitable carrier electrolyte in which diclofenac exhibit the more sensitive adsorption control. The combination of a MWCNT nanostructured carbon paste sensor and the acidic $\mathrm{H}_{2} \mathrm{SO}_{4}$ electrolyte ensure an interesting sensitivity and selectivity of the developed method. Furthermore, the proposed sensor presents a low detection limit of the order of $4 \mathrm{nmol} \mathrm{L}^{-1}$, wide linear concentration range (3 decades), acceptable selectivity, good repeatability and reproducibility (overall less than $8.4 \%$ ), ease of preparation and low cost. In 
addition, the proposed sensor has been applied for the electrochemical determination of diclofenac in real samples with very satisfactory results with recovery percentages for spiked samples very close to $100 \%$ (difference of $2 \%$ maximum). This project is therefore of real interest for the realization of sensors able to quantify traces of diclofenac in real water samples. The low interfering substances like important concentrations of urea and glucose, allow to use this sensor for the determination of dichlofenac in urine.

\section{Conflict of interest}

The authors declare that they have no known competing financial conflicts of interest or personal relationships that could appear to influence the work reported in this paper.

\section{Data Availability Statement:}

Data sharing not applicable to this article as no datasets were generated or analysed during the current study

\section{References}

[1] M. Tunçay, S. Çaliş, H. S. Kaş, M. T. Ercan, İ. Peksoy, A. A. Hincal, Int. J. Pharm. 2000, 195, 179- 188.

[2] M. M. Sein, M. Zedda, J. Tuerk, T. C. Schmidt, A. Golloch, C. Von Sonntag 2008, 42, 6656- 6662.

[3] X. Yang, F. Wang, et S. Hu, Mater. Sci. Eng. C. 2008, 28, 188- 194.

[4] M. Suwalsky, C. Schneider, et H. D. Mansilla, p. 6.

[5] A. Larsson, J. Angbrant, J. Ekeroth, P. Månsson, B. Liedberg, Sens. Actuators B Chem., vol. $2006,113,730-748$.

[6] B. Hoeger, B. Köllner, D. R. Dietrich, B. Hitzfeld, Aquat. Toxicol. Amst. Neth. 2005, 75, 53- 64.

[7] K. Kern, J. Eur. Environ. 2014, 11, 31- 48.

[8] D. Stülten, S. Zühlke, M. Lamshöft, M. Spiteller, Sci. Total Environ. 2008, 405, 310- 316.

[9] A. J. Al-Rajab, L. Sabourin, D. R. Lapen, E. Topp, Sci. Total Environ. 2010, 409, 78- 82. 
[10] D. J. Perisic, M. Kovacic, H. Kusic, U. L. Stangar, V. Marin, A. L. Bozic, React. Kinet. Mech. Catal. 2016, 118, 451- 462.

[11] A. Chmielewska, L. Konieczna, A. Plenis, H. Lamparczyk, J. Chromatogr. B Analyt. Technol. Biomed. Life. Sci. 2006, 839, 102- 111.

[12] B. T. Alquadeib, Saudi Pharm. J. 2019, 27, 66- 70.

[13] M. C. Blanco- López, L. Fernández- Llano, M. J. Lobo- Castañón, A. J. MirandaOrdieres, et P. Tuñón- Blanco, Anal. Lett. 2004, 37, 915- 927.

[14] R. Bhushan, D. Gupta, A. Mukherjee, Biomed. Chromatogr. 2007, 21, 1284- 1290.

[15] M. E. M. Hassouna, H. O. Salem, J. Pharm. Res. Int. 2019, 1- 21.

[16] Z. Malá, P. Gebauer, P. Boček, Anal. Chim. Acta, 2016, 907, 1- 6.

[17] M. Burç, S. Köytepe, S. T. Duran, N. Ayhan, B. Aksoy, et T. Seçkin, Measurement, 2020, $151,107103$.

[18] T. Alizadeh, S. Nayeri, Anal. Bioanal. Chem. 2020, 412, 657- 667.

[19] J. Li and al. Microchim. Acta, 2020, 187, 80.

[20] J. C. Anike et J. L. Abot , Ed. Woodhead Publishing, 2020, 213- 241.

[21] M. A. Chamjangali, N. Goudarzi, G. Bagherian, A. A. Reskety, Measurement, 2015, 71, 23- 30 .

[22] A. Mokhtari, H. Karimi-Maleh, A. A. Ensafi, H. Beitollahi, Sens. Actuators B Chem. 2012, 169, 96- 105.

[23] F. Stan, R. T. Rosculet, C. Fetecau, Measurement. 2019, 136, 345- 355.

[24] P. Daneshgar, P. Norouzi, M. Ganjali, R. Dinarvand, A. Moosavi-Movahedi, Sensors, 2009, 9, 7903- 7918.

[25] A. A. Ensafi, M. Izadi, H. Karimi-Maleh, Ionics, 2013, 19, 137- 144.

[26] K. Sarhangzadeh, A. A. Khatami, M. Jabbari, S. Bahari, J. Appl. Electrochem. 2013, 43, 1217-1224.

[27] R. N. Goyal, S. Chatterjee, A. R. S. Rana, Carbon, 2010, 48, 4136- 4144.

[28] N. C. Honakeri, S. J. Malode, R. M. Kulkarni, N. P. Shetti, Sens. Int. 2020, 1, 100002.

[29] N. P. Shetti and al., Surf. Interfaces, 2017, 9, 107- 113.

[30] A.-L. Gy and al. J. Electroanal. Chem. 2017, 794, 182- 188.

[31] A. Ambrosi, R. Antiochia, L. Campanella, R. Dragone, I. Lavagnini, J. Hazard. Mater. 2005, 122, 219- 225.

[32] A. Afkhami, A. Bahiraei, T. Madrakian, Mater. Sci. Eng. C, 2016, 59, 168- 176. 
[33] B. K. Chethana, S. Basavanna, Y. Arthoba Naik, Ind. Eng. Chem. Res. 2012, 51, 10287- 10295.

[34] M. Arvand, T. M. Gholizadeh, M. A. Zanjanchi, Mater. Sci. Eng. C, 2012, 32, 1682- 1689.

[35] M. F. Guzmán, L. H. Mendoza Huizar, C. A. Galán Vidal, G. R. Morales, G. A. Álvarez Romero, Curr. Anal. Chem., 2019, 15, 294- 304.

[36] F. Manea, M. Ihos, A. Remes, G. Burtica, J. Schoonman, Electroanalysis, 2010, 22, 2058- 2063.

[37] L. Fernández-Llano, M. C. Blanco-López, M. J. Lobo-Castañón, A. J. Miranda-Ordieres, P. Tuñón-Blanco, Electroanalysis. 2007, 19, 1555- 1561.

[38] M. Hajjizadeh, A. Jabbari, H. Heli, A. A. Moosavi-Movahedi, S. Haghgoo, Electrochimica Acta, 2007, 53, 1766- 1774.

[39] Md. Shalauddin, S. Akhter, W. J. Basirun, S. Bagheri, N. S. Anuar, M. R. Johan, Electrochimica Acta, 2019, 304, 323- 333.

[40] S. L. Z. Jiokeng, I. K. Tonle, A. Walcarius, Sens. Actuators B Chem. 2019, 287, 296- 305.

[41] M. Mostafavi, M. R. Yaftian, F. Piri, H. Shayani-Jam, Biosens. Bioelectron. 2018, 122, 160- 167.

[42] C. Slim, N. Tlili, C. Richard, S. Griveau, F. Bedioui, Inorg. Chem. Commun. 2019, 107, 107454.

[43] M. M. Eteya, G. H. Rounaghi, B. Deiminiat, Microchem. J. 2019, 144, 254- 260. 
Figures

Fig 1

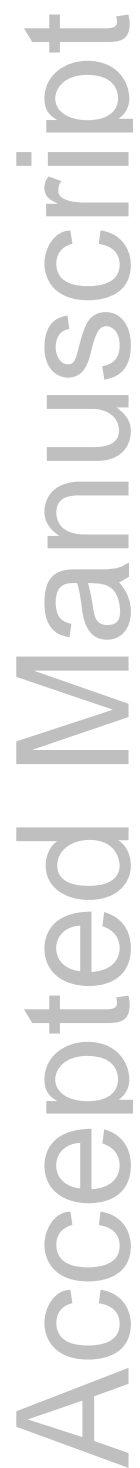




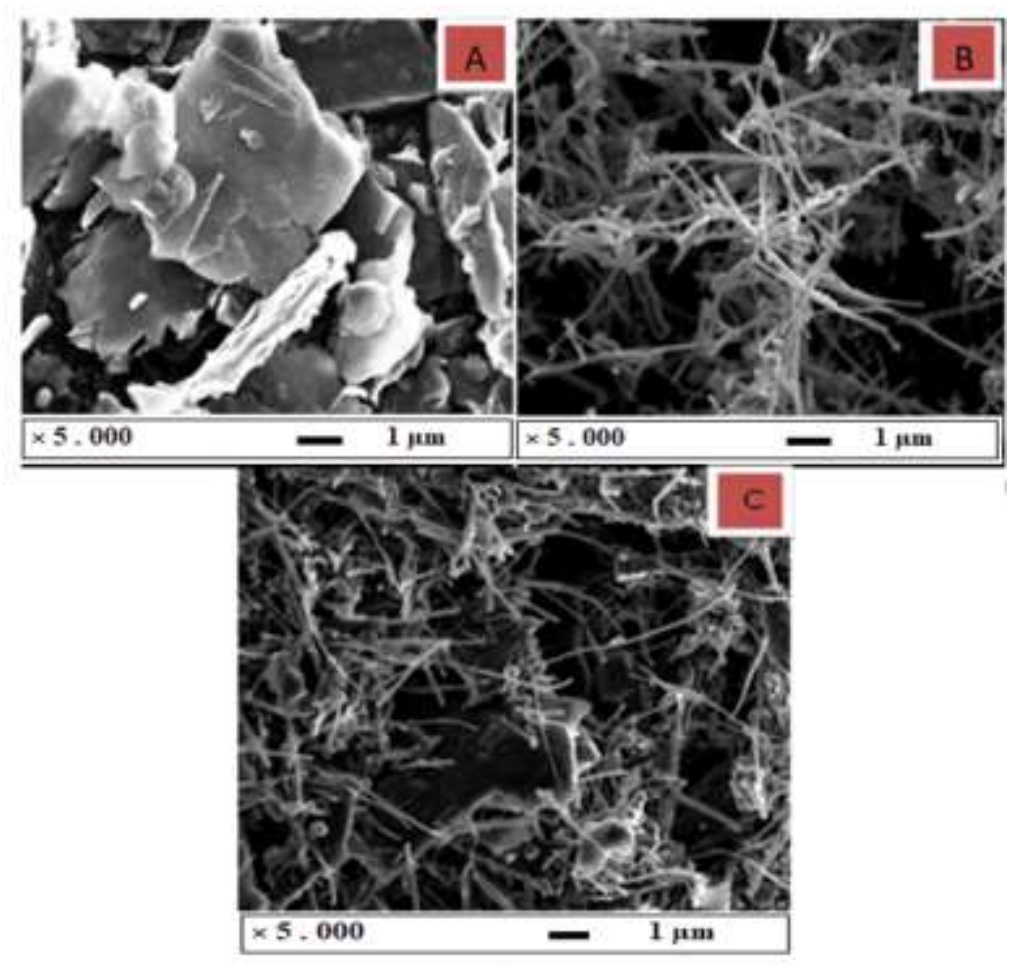

Figure 1. SEM images of $\mathrm{G}(A), \operatorname{MWCNT}(B)$ and $(\mathrm{G}-\mathrm{MWCNT})-\mathrm{CPE}_{3}(C)$

\section{Fig 2}

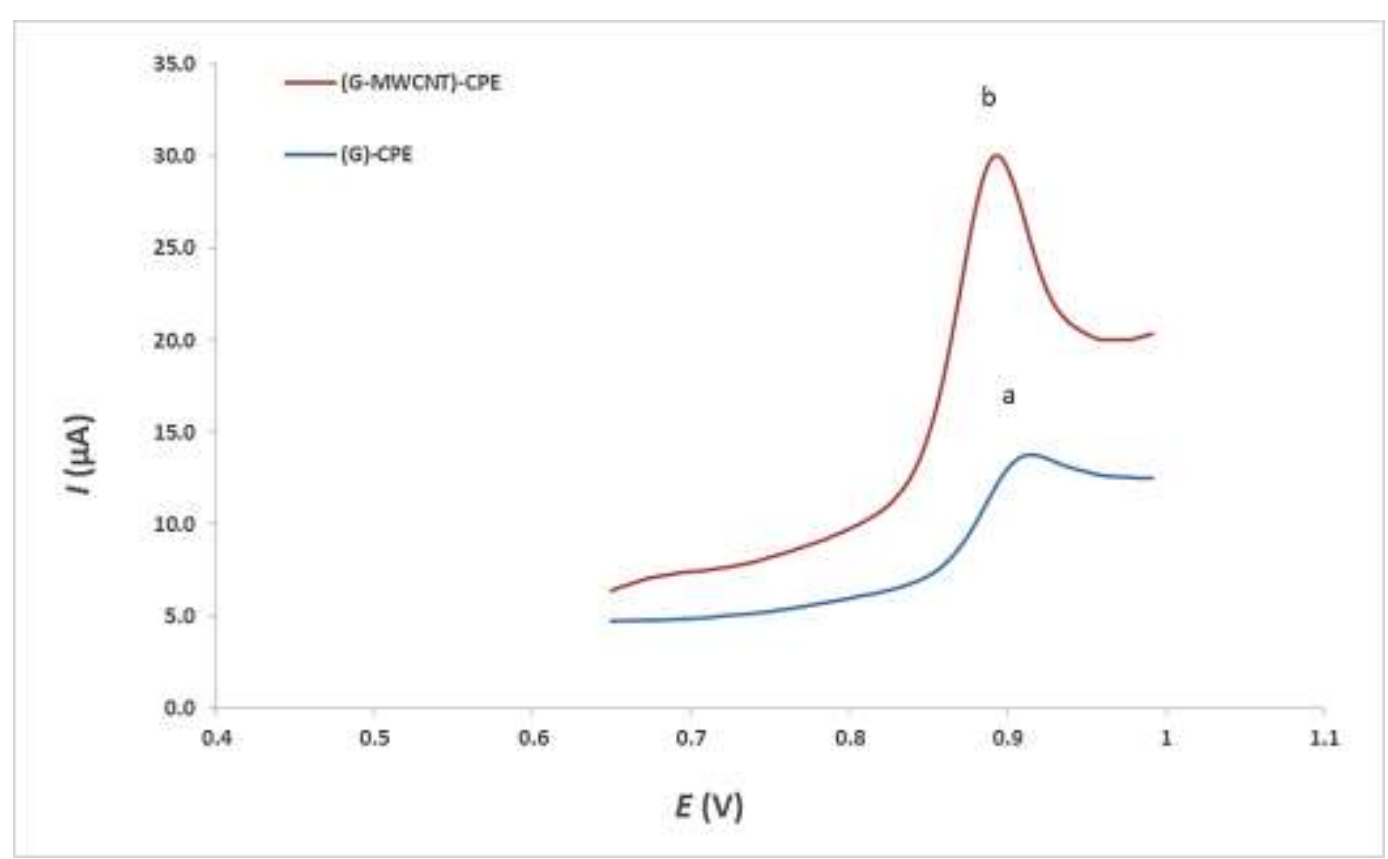

Figure 2. Voltammograms obtained using the (G)-CPE and (G-MWCNT)-CPE 3 for $510^{-6} \mathrm{~mol} \mathrm{~L}^{-1}$ diclofenac in $\mathrm{H}_{2} \mathrm{SO}_{4} 0.25 \mathrm{M}+\mathrm{KCl} 0.25 \mathrm{M}$ with scan rate of $30 \mathrm{mV} \mathrm{s}^{-1}$; preconcentration time 10 min..

Fig 3 


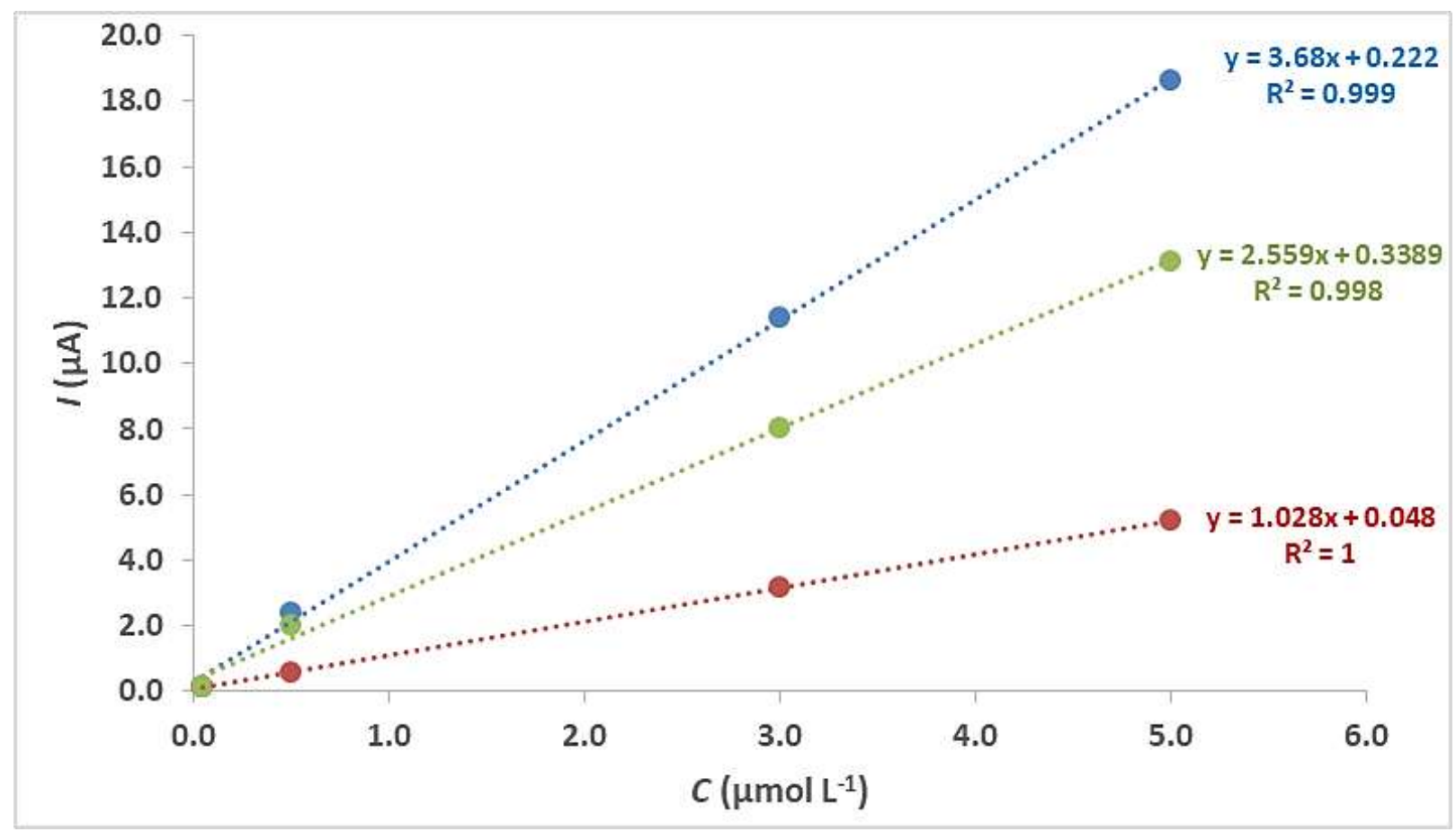

Figure 3. Variation of the intensity of peak current $I \mathrm{p}$ as a function of diclofenac concentration $\left(510^{-8}, 510^{-7}, 3\right.$ $10^{-6}$ and $510^{-6} \mathrm{~mol} \mathrm{~L}^{-1}$ ), for the different carbon pastes (G-MWCNT)-CPE1 (a), (G-MWCNT)-CPE 2 (b) and (G-

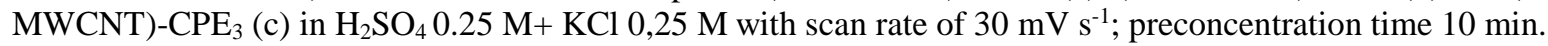

\section{Fig 4}

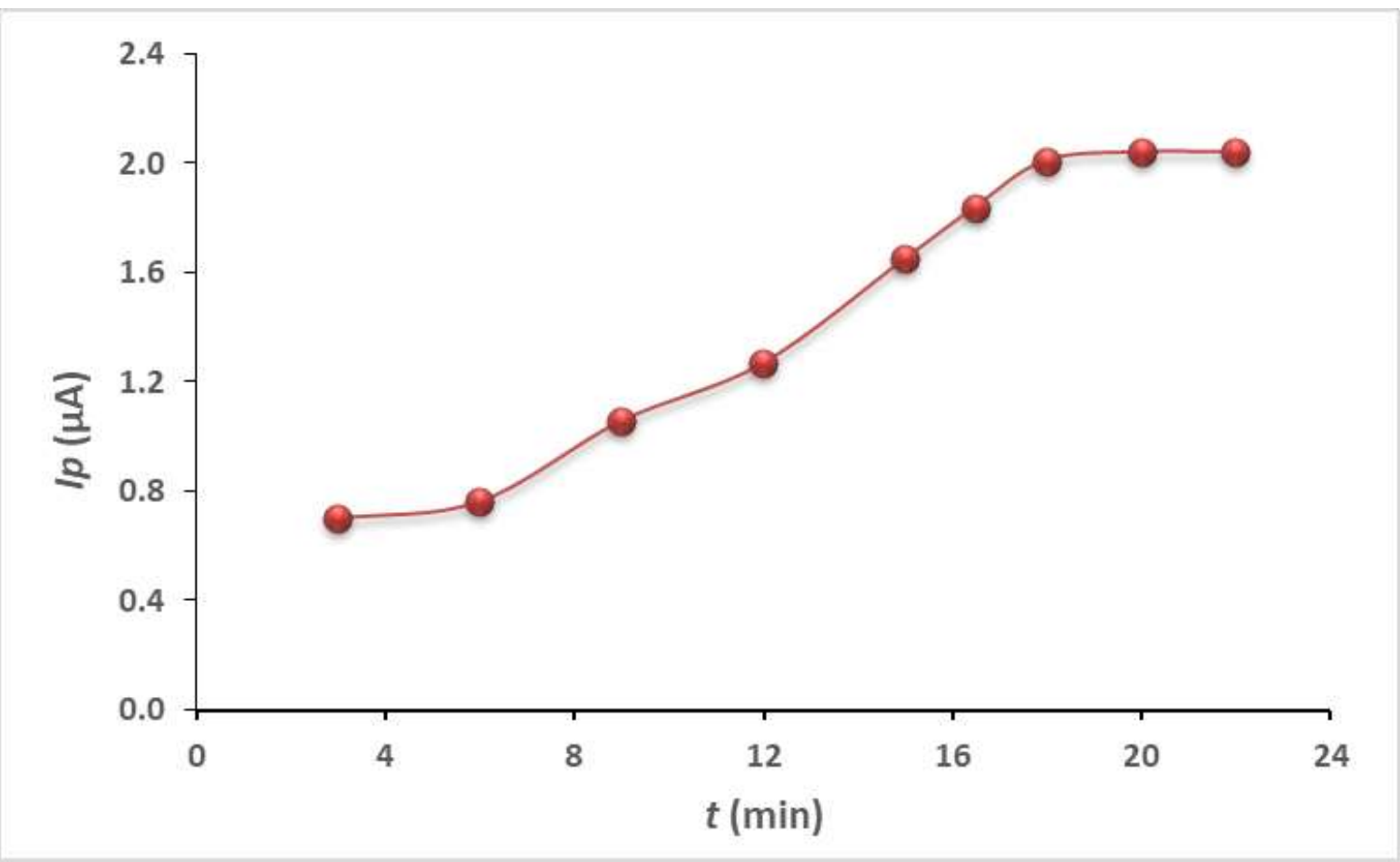

Figure 4. Effect of pre-concentration time on the peak current response at (G-MWCNT)-CPE $\mathrm{C}_{3}$ in $10^{-7} \mathrm{~mol} \mathrm{~L}^{-1}$ of diclofenac in $\mathrm{H}_{2} \mathrm{SO}_{4} 0.25 \mathrm{M}+\mathrm{KCl} 0.25 \mathrm{M}$ with scan rate of $30 \mathrm{mV} \mathrm{s}^{-1}$, under magnetic stirring (300 rpm) 
Fig 5

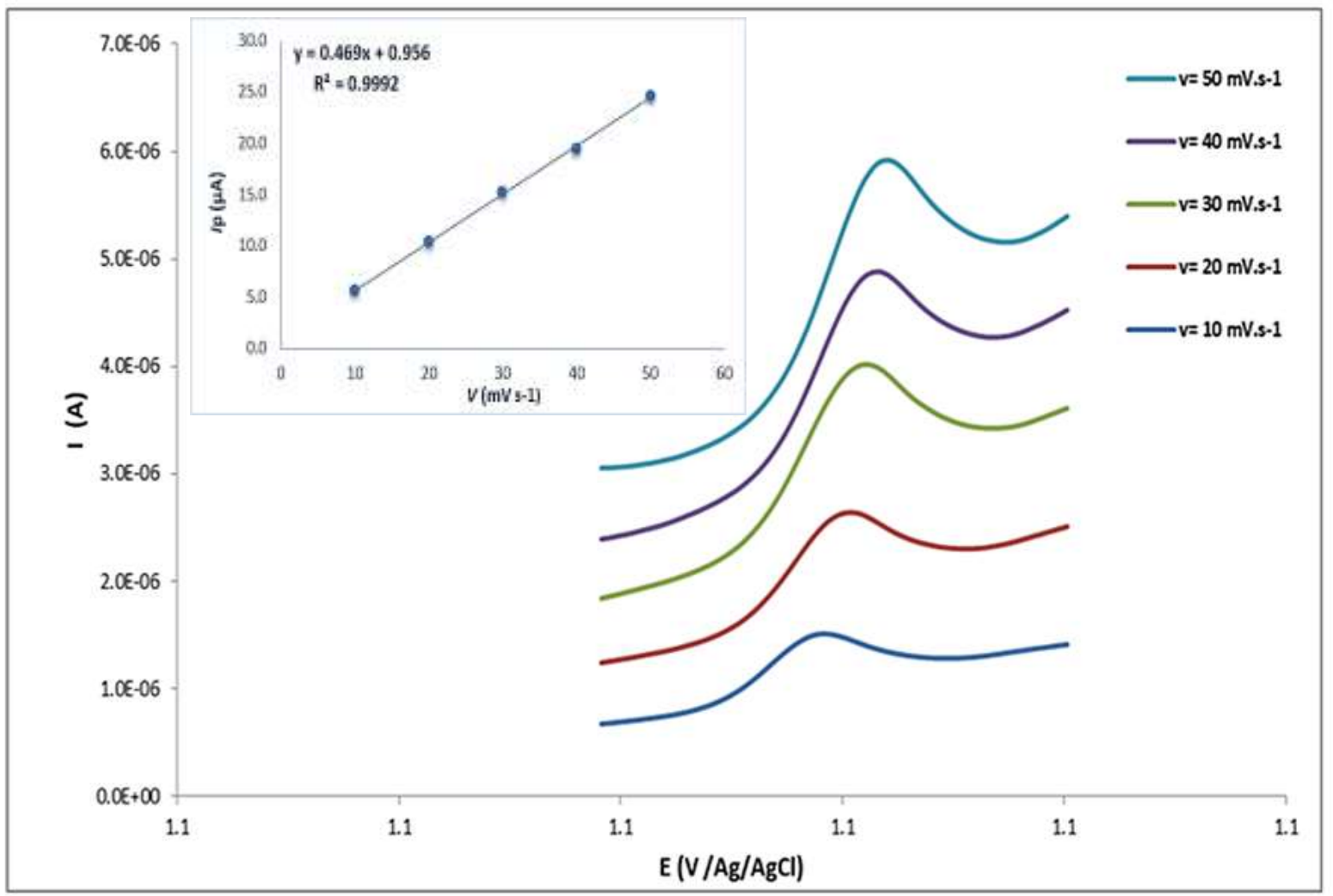

Figure 5. Effect scan rate potential $\left(10-50 \mathrm{mV} \mathrm{s}^{-1}\right)$ on the (G-MWCNT)-CPE $\mathrm{E}_{3}$ voltammetric response in $\mathrm{H}_{2} \mathrm{SO}_{4}$ $0.25 \mathrm{M}+\mathrm{KCl} 0.25 \mathrm{M}$ containing $1 \mu \mathrm{mol} . \mathrm{L}^{-1}$ of diclofenac

\section{Fig 6}

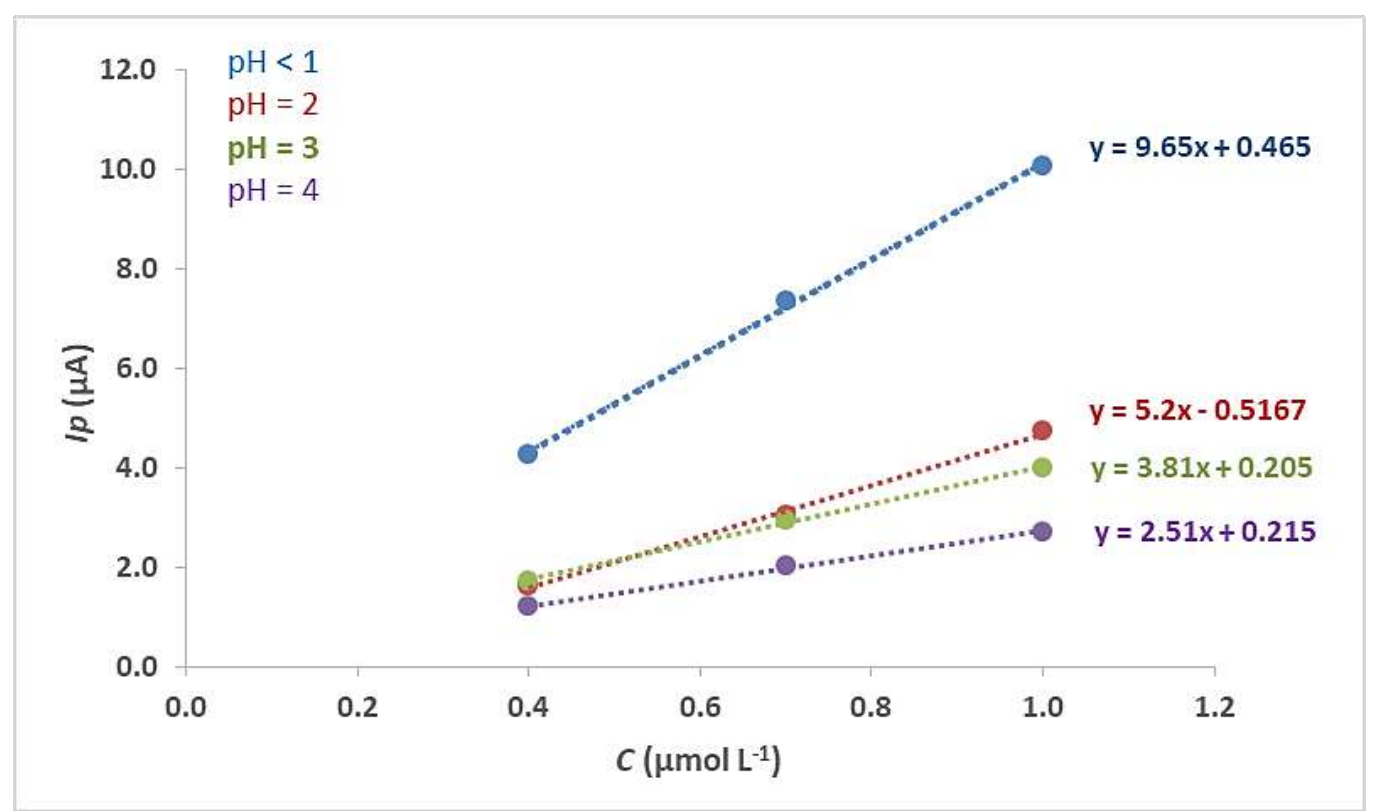

Figure 6. $\mathrm{pH}$ effect on the voltammetric response of the (G-MWCNT)-CPE 3 electrode for different concentrations of diclofenac $\left(0.4,0.7\right.$ and $\left.1.010^{-6} \mathrm{~mol} \mathrm{~L}^{-1}\right)$ in $\mathrm{H}_{2} \mathrm{SO}_{4} 0.25 \mathrm{M}+\mathrm{KCl} 0.25 \mathrm{M}$ electrolyte at scan rate of $30 \mathrm{mV} \mathrm{s}^{-1}$, preconcentration time $18 \mathrm{~min}(300 \mathrm{rpm})$. 


\section{Fig 7}

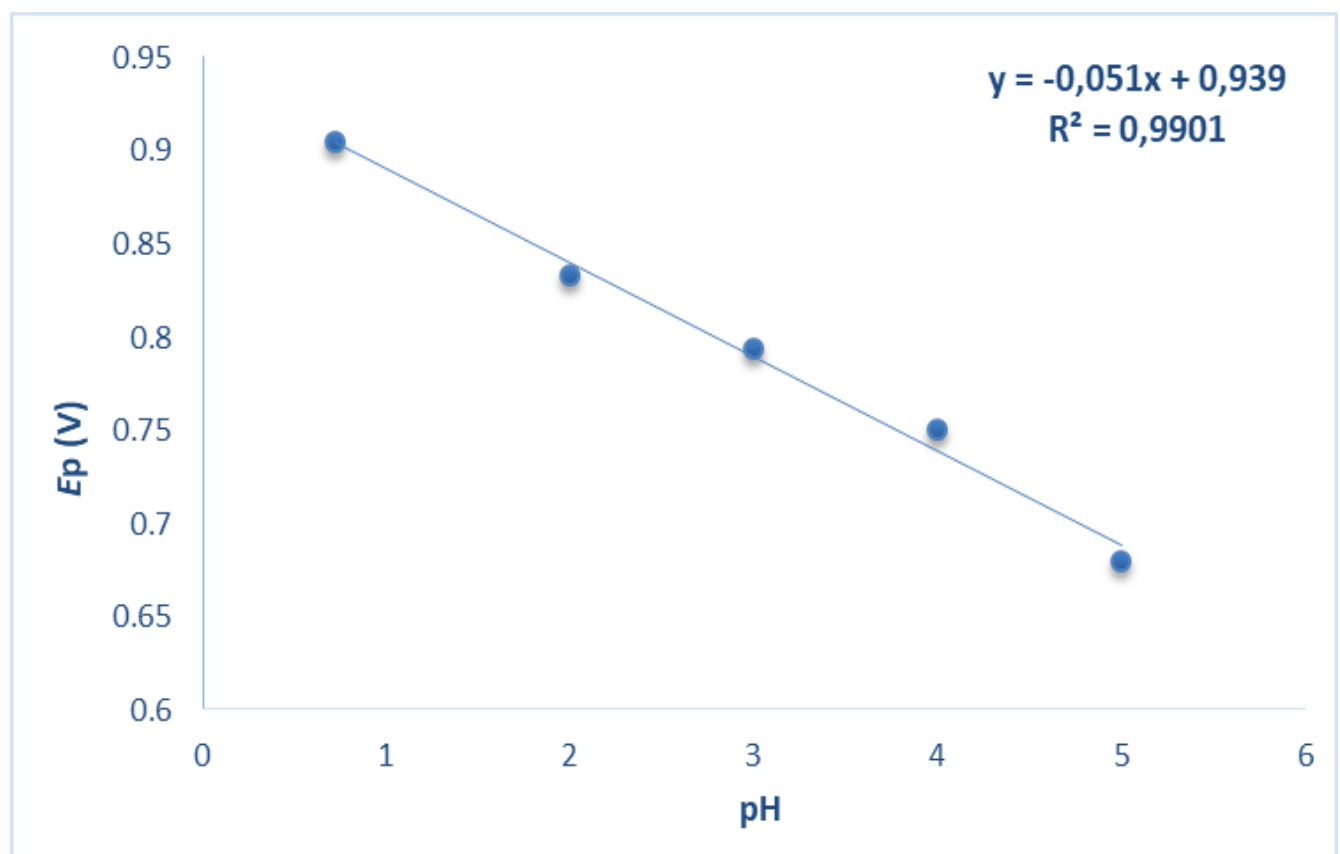

Figure 7. Variation of the peak potential $E \mathrm{p}$ for different $\mathrm{pH}(0,7-5)$ for voltammetry of $1 . \mu \mathrm{mol} \mathrm{L}^{-1} \mathrm{DCF}$ in $\mathrm{H}_{2} \mathrm{SO}_{4} 0.25 \mathrm{M}+\mathrm{KCl} 0.25 \mathrm{M}$ electrolyte with (G-MWCNT)-CPE 3 at scan rate of $30 \mathrm{mV} \mathrm{s}^{-1}$

\section{Fig 8}

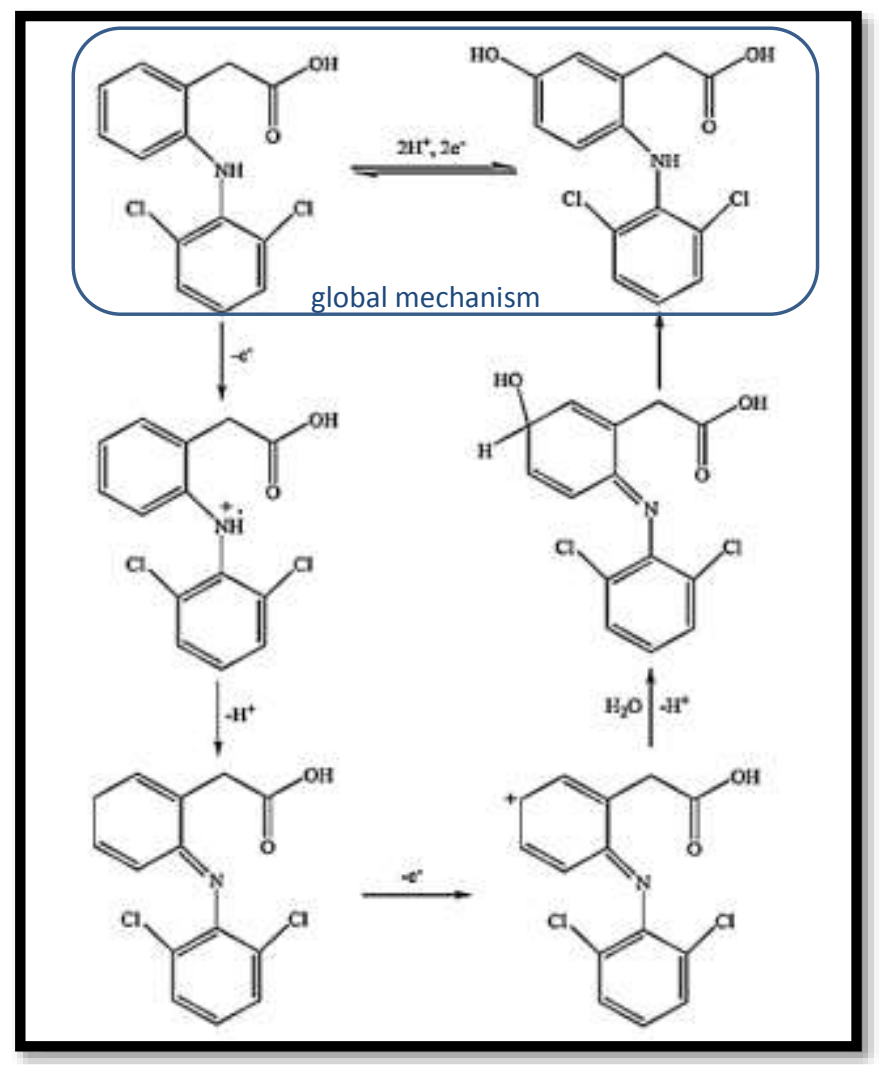

Figure 8. Probable mechanism of electrooxidation of diclofenac 


\section{Fig 9}

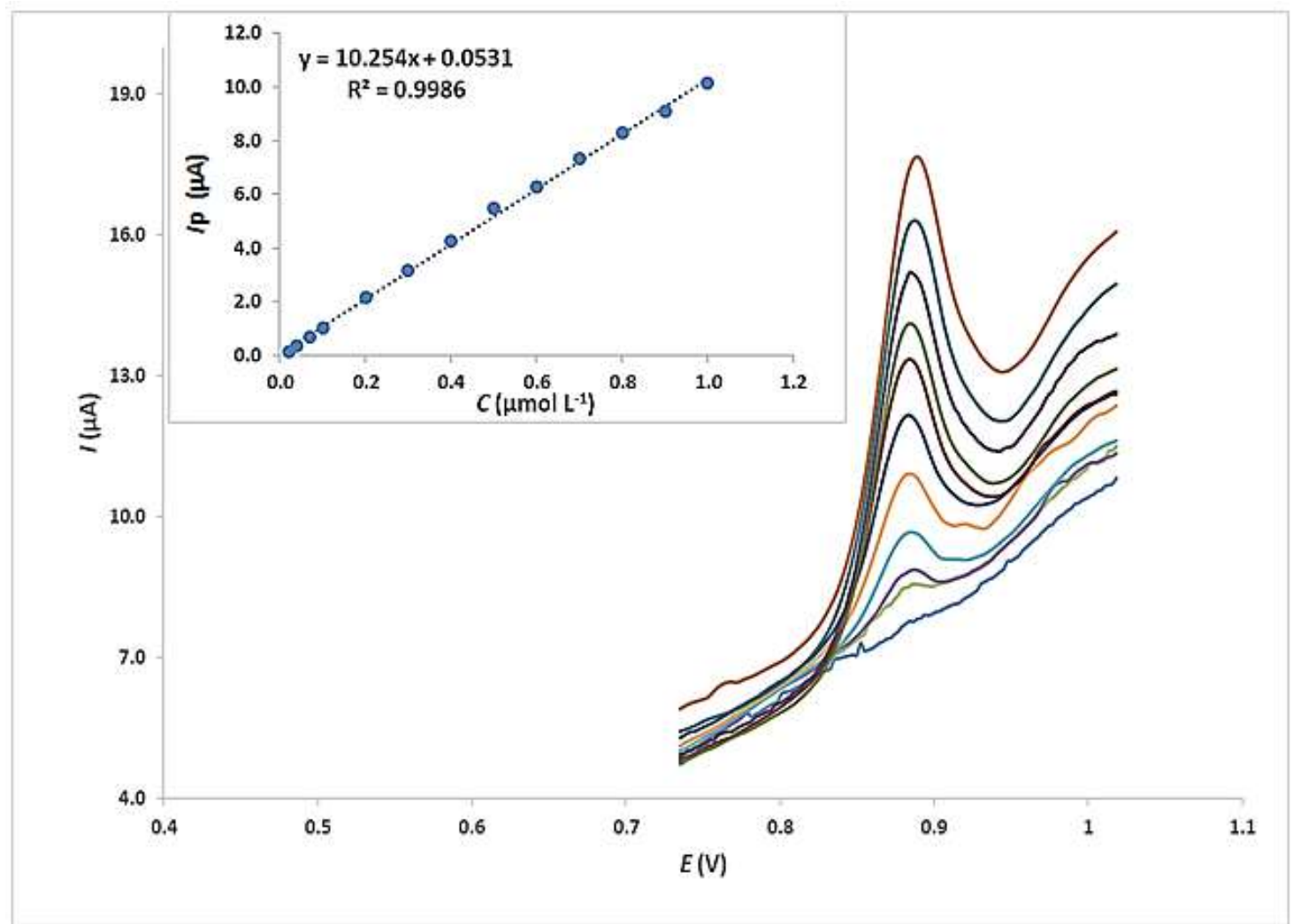

Figure 9. Voltammograms and calibration curve obtained at (G-MWCNT)-CPE in $_{2} \mathrm{H}_{2} \mathrm{SO}_{4} 0.25 \mathrm{M}+\mathrm{KCl} 0.25 \mathrm{M}$ for diclofenac concentrations from $0.02-1 \mu \mathrm{mol} \mathrm{L}^{-1}\left(v=30 \mathrm{mV} \mathrm{s}^{-1}\right)$; preconcentration time: $18 \mathrm{~min}$. $(300 \mathrm{rpm})$

\section{Fig 10}

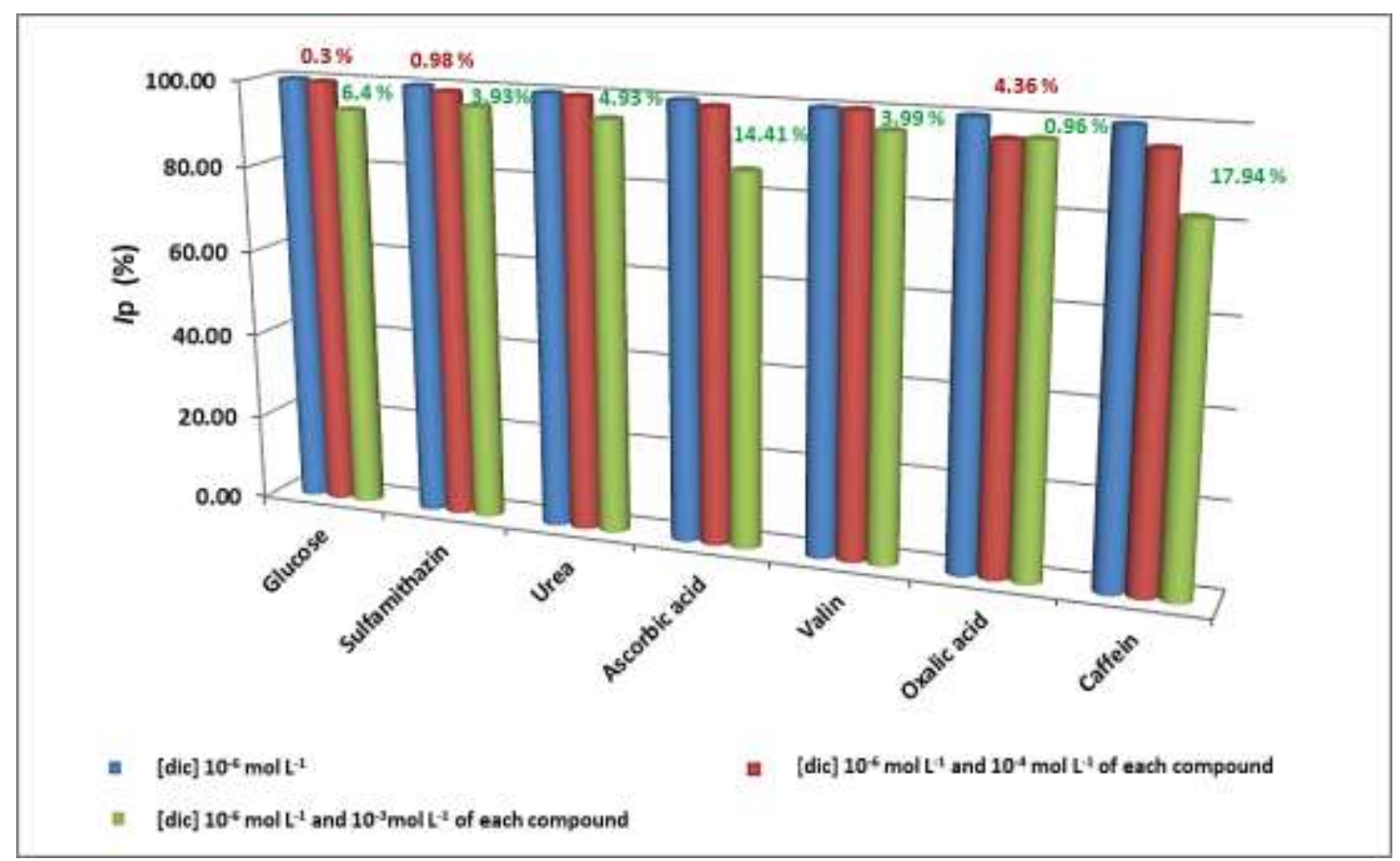

Figure 10. Influence of interfering compounds on DCF oxidation peak current obtained for voltammetric determination of diclofenac under optimized experimental conditions $\left(\mathrm{H}_{2} \mathrm{SO}_{4} 0.25 \mathrm{M}+\mathrm{KCl} 0.25 \mathrm{M} ; v=30 \mathrm{mV} \mathrm{s}\right.$; preconcentration time: $18 \mathrm{~min}$. (300 rpm) 


\section{Figure captions}

Figure 1. SEM images of $G(A)$, MWCNT (B) and (G-MWCNT)-CPE $E_{3}(C)$..

Figure 2. Voltammograms obtained using the (G)-CPE and (G-MWCNT)-CPE 3 for $510^{-6} \mathrm{~mol} \mathrm{~L}^{-1}$ diclofenac in $\mathrm{H}_{2} \mathrm{SO}_{4} 0.25 \mathrm{M}+\mathrm{KCl} 0.25 \mathrm{M}$ with scan rate of $30 \mathrm{mV} \mathrm{s}^{-1}$; preconcentration time 10 min.. 16 Figure 3. Variation of the intensity of peak current $/ p$ as a function of diclofenac concentration $\left(510^{-8}\right.$, $510^{-7}, 310^{-6}$ and $510^{-6} \mathrm{~mol} \mathrm{~L}^{-1}$ ), for the different carbon pastes (G-MWCNT)-CPE1 (a), (G-MWCNT)$\mathrm{CPE}_{2}$ (b) and (G-MWCNT)-CPE (c) in $\mathrm{H}_{2} \mathrm{SO}_{4} 0.25 \mathrm{M}+\mathrm{KCl} 0,25 \mathrm{M}$ with scan rate of $30 \mathrm{mV} \mathrm{s}^{-1}$; preconcentration time $10 \mathrm{~min}$.

Figure 4. Effect of pre-concentration time on the peak current response at (G-MWCNT)-CPE 3 in $210^{-7}$ mol L-1 of diclofenac in $\mathrm{H}_{2} \mathrm{SO}_{4} 0.25 \mathrm{M}+\mathrm{KCl} 0.25 \mathrm{M}$ with scan rate of $30 \mathrm{mV} \mathrm{s}^{-1}$, under magnetic stirring (300 rpm)

Figure 5. Effect scan rate potential $\left(10-50 \mathrm{mV} \mathrm{s}^{-1}\right)$ on the (G-MWCNT)-CPE 3 voltammetric response in $\mathrm{H}_{2} \mathrm{SO}_{4} 0.25 \mathrm{M}+\mathrm{KCl} 0.25 \mathrm{M}$ containing $1 \mu \mathrm{mol} . \mathrm{L}^{-1}$ of diclofenac.

Figure 6. $\mathrm{pH}$ effect on the voltammetric response of the (G-MWCNT)-CPE $E_{3}$ electrode for different concentrations of diclofenac $\left(0.4,0.7\right.$ and $\left.1.010^{-6} \mathrm{~mol} \mathrm{~L}^{-1}\right)$ in $\mathrm{H}_{2} \mathrm{SO}_{4} 0.25 \mathrm{M}+\mathrm{KCl} 0.25 \mathrm{M}$ electrolyte at scan rate of $30 \mathrm{mV} \mathrm{s}^{-1}$, preconcentration time $18 \mathrm{~min}$ (300 rpm).

Figure 7. Variation of the peak potential $\mathrm{Ep}$ for different $\mathrm{pH}(0,7-5)$ for voltammetry of $1 . \mu \mathrm{mol} \mathrm{L}^{-1} \mathrm{DCF}$ in $\mathrm{H}_{2} \mathrm{SO}_{4} 0.25 \mathrm{M}+\mathrm{KCl} 0.25 \mathrm{M}$ electrolyte with (G-MWCNT)-CPE 3 at scan rate of $30 \mathrm{mV} \mathrm{s}^{-1}$..... 19

Figure 8. Probable mechanism of electrooxidation of diclofenac

Figure 9. Voltammograms and calibration curve obtained at (G-MWCNT)-CPE in $_{3} \mathrm{H}_{2} \mathrm{SO}_{4} 0.25 \mathrm{M}+\mathrm{KCl}$ $0.25 \mathrm{M}$ for diclofenac concentrations from $0.02-1 \mu \mathrm{mol} \mathrm{L}^{-1}\left(v=30 \mathrm{mV} \mathrm{s}^{-1}\right)$; preconcentration time: 18 $\min .(300 \mathrm{rpm})$

Figure 10. Influence of interfering compounds on DCF oxidation peak current obtained for voltammetric determination of diclofenac under optimized experimental conditions $\left(\mathrm{H}_{2} \mathrm{SO}_{4} 0.25 \mathrm{M}+\right.$ $\mathrm{KCl} 0.25 \mathrm{M} ; \mathrm{v}=30 \mathrm{mV} \mathrm{s}^{-1}$; preconcentration time: $18 \mathrm{~min}$. (300 rpm) 


\section{Tables}

Tab 1

\begin{tabular}{ccc}
\hline $\begin{array}{c}\text { Concentration of } \\
\text { diclofenac }\left(\times 10^{-7} \mathrm{~mol} \mathrm{~L}^{-1}\right)\end{array}$ & $\begin{array}{c}\text { Repeatability of Ip } \\
\mathrm{RSD}^{*}(\%)\end{array}$ & $\begin{array}{c}\text { Reproducibility of Ip } \\
\mathrm{RSD}^{*}(\%)\end{array}$ \\
\hline 1 & 2.4 & 8.4 \\
4 & 3.5 & 5.3 \\
7 & 2.2 & 4.5 \\
10 & 1.3 & 2.4 \\
\hline
\end{tabular}

$* \mathrm{n}=\overline{(4)}$

Table 1. Study of repeatability and reproducibility at (G-MWCNT)-CPE $\mathrm{C}_{3}$ electrode (in $\mathrm{H}_{2} \mathrm{SO}_{4} 0.25 \mathrm{M}+\mathrm{KCl}$ $0.25 \mathrm{M})$, in the diclofenac concentration range of 0,1 and $1 \mu \mathrm{mol} \mathrm{L}^{-1},\left(v=30 \mathrm{mV} \cdot \mathrm{s}^{-1}\right)$.

Tab 2

\begin{tabular}{lcccc}
\hline Samples & $\begin{array}{c}\text { Added } \\
\text { diclofenac } \\
(\mathrm{nM})\end{array}$ & $\begin{array}{c}\text { Found } \\
\text { diclofenac } \\
(\mathrm{nM})\end{array}$ & $\begin{array}{c}\text { RSD* } \\
(\%)\end{array}$ & $\begin{array}{c}\text { Recovery } \\
(\%)\end{array}$ \\
\hline Tap water & 200 & $204 \pm 7^{* *}$ & 2.5 & 101.9 \\
\hline Lake water & 300 & $296 \pm 3^{* *}$ & 0.6 & 98.9 \\
\hline (4) $* *$ Confidence interval for $\alpha=0.05$. & & &
\end{tabular}

Table 2. Analysis of tap and lake water samples spicked with diclofenac at (G-MWCNT)-CPE 3 electrode with standard addition determination $\left(v=30 \mathrm{mV} \mathrm{s}^{-1}\right)$; preconcentration time: $18 \mathrm{~min}$. (300 rpm)) 
Tab 3

\begin{tabular}{|c|c|c|c|}
\hline Electrode & $\begin{array}{l}\text { Linear range } \\
\left.(\mu \mathrm{mol} \mathrm{L})^{-1}\right)\end{array}$ & $\begin{array}{l}\text { LOD } \\
\left(\mu \mathrm{mol} \mathrm{L}{ }^{-1}\right)\end{array}$ & Ref \\
\hline Graphite & $2.56-9.5$ & 0.76 & {$[30]$} \\
\hline Carbon paste/CNTs & $2-100$ & 0.8 & [31] \\
\hline AuNPs/MWCNT/CCE & $0.03-200$ & 0.02 & [32] \\
\hline TCPE & $10-140$ & 3.28 & {$[33]$} \\
\hline $\mathrm{MCNT} / \mathrm{Cu}(\mathrm{OH})_{2}$ & $0.18-119$ & 0.04 & [34] \\
\hline IL/CNTPE & $0.3-750$ & 0.09 & [35] \\
\hline $\mathrm{Cu}$-ZEGE & $3-15$ & 0.3 & {$[36]$} \\
\hline DCF-MIP & $0.005-0.54$ & 0.0016 & [37] \\
\hline NHMN & $196-2650$ & 31.7 & {$[38]$} \\
\hline EPPGE & $0.025-1.5$ & 0.02 & [27] \\
\hline HN/f-MWCNTs / GC & $0.05-1.00$ & 0.012 & [39] \\
\hline GCE/APTES-Amino-AT-Silica & $0.3-20$ & 0.053 & [40] \\
\hline $\mathrm{P}(\mathrm{rGO})-\mathrm{t} / \mathrm{IP}$ & $16-270$ & 3 & {$[41]$} \\
\hline COOH-(f-MWCNTs) /(GCE) & $2-15$ & 0.1 & {$[42]$} \\
\hline $\mathrm{Au}-\mathrm{Pt}$ b/MWCNT & $0.5-1000$ & 0.03 & [44] \\
\hline (G-MWCNT)-CPE & $0.02-1$ & 0.004 & This work \\
\hline \multicolumn{4}{|c|}{$\begin{array}{l}\text { TCPE : Tyrosine-modified carbon paste electrode; NHMN : nickel hydroxide-modified nickel ; EPPGE : edge- } \\
\text { plane pyrolytic graphite electrode ; HN : Hybrid nanocellulose } P(r G O)-t / I P \text { Polyaniline-reduced graphene } \\
\text { oxide -triphenylamin / Imprinted polymer; COOH-(f-MWCNTs)/(GCE):COOH-functionalized multi-walled } \\
\text { carbon nanotubes film coated on the glassy carbon electrode; Au-Pt b/MWCNT:Au-Pt bimetallic nanoparticles } \\
\text { decorated multi-walled carbon nanotubes. }\end{array}$} \\
\hline
\end{tabular}

Table 3. Comparison of analytical performances with subsequent work 


\section{Table caption}

Table 1. Study of repeatability and reproducibility at (G-MWCNT)-CPE 3 electrode (in $\mathrm{H}_{2} \mathrm{SO}_{4}$ $0.25 \mathrm{M}+\mathrm{KCl} 0.25 \mathrm{M})$, in the diclofenac concentration range of 0,1 and $1 \mu \mathrm{mol} \mathrm{L}{ }^{-1},\left(\mathrm{v}=30 \mathrm{mV} \cdot \mathrm{s}^{-}\right.$ $1)$.

Table 2. Analysis of tap and lake water samples spicked with diclofenac at (G-MWCNT)-CPE 3 electrode with standard addition determination $\left(\mathrm{v}=30 \mathrm{mV} \mathrm{s}^{-1}\right)$; preconcentration time: 18 min. (300 rpm)) 22

Table 3. Comparison of analytical performances with subsequent work 23

\section{Highlights}

- Development of a simple and sensitive sensor (G-MWCNT)-CPE 3 for the detection of traces of diclofenac in water.

- In order to produce a nano-structured sensitive surface of the CPE the Nano-Materials (NWCNT) was incorporated into the carbon paste.

- The higher sensitivity, good selectivity (due to specific adsorption in acidified water), repeatability and reproducibility are the main features of the proposed electrochemical sensor.

- This proposed method was successfully used to detect diclofenac in contaminated local tap water and lake water.

- An 100-fold lower limit of DCF detection preconcentrated on the surface modified carbon paste electrodes. 